\title{
Peran Selenium pada Diare Akut
}

\author{
Nolitriani ${ }^{1}$, Yusri Dianne Jurnalis ${ }^{2}$, Yorva Sayoeti ${ }^{2}$ \\ ${ }^{1}$ Fakultas Kedokteran Universitas Andalas/RSUP Dr. M. Djamil Padang \\ ${ }^{2}$ Subbagian Gastrohepatologi Anak Bagian Anak Fakultas Kedokteran Universitas Andalas/RSUP Dr. M. Djamil Padang
}

\section{A B S T R A C T}

\begin{abstract}
Latar Belakang. Diare cair akut merupakan salah satu manifestasi gangguan fungsi saluran cerna. Umumnya episode diare adalah akut, bila berlangsung lebih dari 14 hari disebut diare persisten. Diare masih merupakan penyebab kematian utama pada bayi dan anak di Indonesia. Menurut Riset Kesehatan Dasar yang diselenggarakan Departemen Kesehatan Republik Indonesia, berdasarkan penyakit menular, diare menempati urutan ketiga setelah tuberkulosis dan pneumonia. Di Indonesia, dilaporkan tiap anak mengalami diare sebanyak 411 per 1000 episode per tahun dengan angka kesakitan dan kematian masih tetap tinggi. Oleh karena itu, diperlukan penanganan yang komprehensif dan rasional. Penelitian mendapatkan bahwa defisiensi mikronutrien tertentu dapat berhubungan dengan penyakit diare. Penelitian mengenai zink telah banyak diketahui, namun hanya sedikit penelitian tentang mikronutrien yang lain seperti selenium yang diduga juga terlibat dalam proses diare akut.

Penyakit gastrointestinal dinilai sebagai suatu stress oksidatif. Selenium yang mengandung enzim gastrointestinal glutathione peroxidase (GPx2/ GPx GI) yang paling banyak ditemukan dalam mukosa epitel traktus gastrointestinal. Pada diare terjadi defisiensi selenium yang dapat meningkatkan stress oksidatif dan menurunkan differensiasi dan proliferasi sel $T$ dan menurunkan toksisitas limfosit $\mathrm{T}$. Hal ini memunculkan hipotesis bahwa selenium memegang peranan dalam proses penyembuhan diare akut.
\end{abstract}

Kata kunci: diare akut, selenium, antioksidan, mikronutrien

Background. Acute diarrhea is a manifestation of gastrointestinal dysfunction. If it lasts more than 14 days is called persistent diarrhea. Diarrhea is still the leading cause of death in infants and children in Indonesia. According to Riset Kesehatan Dasar conducted by the Ministry of Health in Indonesia, diarrhea is the third cause of death after tuberculosis and pneumonia. It is reported that each child experiences 411 diarrhea per 1000 episodes per year with high morbidity and mortality. Therefore, comprehensive and rational handling is needed. Research has found that certain micronutrient deficiencies can be associated with diarrheal disease. Research on zinc has been widely known, but only a little research on other micronutrients such as selenium which is thought to also be involved in the process of acute diarrhea.
Gastrointestinal disease is considered as oxidative stress. Selenium contains the gastrointestinal glutathione peroxidase (GPx2 / GPX GI) enzyme which commonly found in the epithelial mucosa of the gastrointestinal tract. In diarrhea, selenium deficiency can increase oxidative stress and reduce the differentiation and proliferation of $T$ cells and reduce the toxicity of $T$ lymphocytes. This raises the hypothesis that selenium plays a role in the process of acute diarrhea.

Keywords: acute diarrhea, selenium, antioxidant, micronutrient

\section{Apa yang sudah diketahui tentang topik ini?}

- Sejak tahun 1980-an, telah dimulai penelitian tentang defisiensi mikronutrien tertentu dengan penyakit diare.

- Zink telah terbukti dapat menurunkan frekuensi, berat serta morbiditas diare akut.

\section{Apa yang ditambahkan pada studi ini?}

Mikronutrein yang lain seperti selenium diduga memiliki peranan dalam proses diare akut karena menjaga keseimbangan antara pro-oksidan dan antioksidan yang berperan pada proses terjadinya diare akut.

\section{CORRESPONDING AUTHOR}

Name: Nolitriani

Phone: +6285272096450

E-mail: o_iporta@yahoo.com

\section{ARTICLE INFORMATION}

Received: September $23^{\text {rd }}, 2020$

Revised: October $15^{\text {th }}, 2020$

Available online: October $31^{\text {st }}$, 2020 


\section{Pendahuluan}

Diare cair akut didefinisikan sebagai penyakit yang ditandai peningkatan frekuensi buang air besar $\geq 3 \mathrm{x}$ per hari dengan konsistensi tinja yang lunak atau cair dan berlangsung kurang dari 14 hari.1 Dari beberapa penelitian di Indonesia tentang penyebab diare akut, rotavirus merupakan penyebab tersering, dengan penyebaran tersering melalui transmisi faecaloral, dan masa inkubasi 1 sampai 3 hari. $^{2}$

Diare masih merupakan penyebab kematian utama pada bayi dan anak di Indonesia. Menurut Riset Kesehatan Dasar (Rikesdas 2007) yang diselenggarakan Departemen Kesehatan Republik Indonesia (Depkes RI), berdasarkan penyakit menular, diare menempati urutan ketiga setelah tuberkulosis dan pneumonia. ${ }^{3}$

Di Indonesia, dilaporkan tiap anak mengalami diare sebanyak 411 per 1000 episode per tahun (Depkes, 2010). Berdasarkan Survei Morbiditas diare 2010, prevalensi diare pada anak tertinggi terjadi pada usia 6-11 bulan (21,65\%), 12-17 bulan (14,43\%) dan 24-29 bulan (12,37\%). Walaupun persentase diare sebagai penyebab kematian pada anak di Indonesia cenderung menurun tetapi angka kesakitan dan kematian masih tetap tinggi. ${ }^{3}$

Sejak tahun 1980-an, beberapa peneliti telah mulai mempertanyakan apakah defisiensi mikronutrien tertentu dapat berhubungan dengan penyakit diare. ${ }^{4}$ Suatu penelitian meta-analisis mengemukakan zink telah terbukti dapat menurunkan frekuensi, berat serta morbiditas diare akut. 5 Mikronutrein yang lain seperti selenium diduga memiliki peranan dalam proses diare akut namun penelitian mengenai hubungan diare akut dengan selenium sangat sedikit. ${ }^{6}$

\section{Patofisiologi Diare Akut}

Pada diare terjadi peningkatan sekresi dan penurunan absorpsi, sehingga akan terjadi kehilangan cairan dan elektrolit dari saluran pencernaan. Mekanisme patofisiologi terjadinya diare cair ada 2 macam yaitu 1 :

1. Diare sekretorik

Disebabkan oleh toksin yang dihasilkan oleh bakteri atau virus. Toksin akan merangsang siklik AMP, siklik GMP dan Ca2+ sehingga kripta melakukan sekresi aktif $\mathrm{Cl}$ - dan menghambat absorbsi $\mathrm{Na}+, \mathrm{Cl}-$ dan HCO3-, oleh karena itu absorbsi $\mathrm{Na}+$ oleh villi gagal dan sekresi $\mathrm{Cl}$ - di sel epitel berlangsung terus menerus atau meningkat. Hasil akhir adalah sekresi cairan yang mengakibatkan kehilangan air dan elektrolit dari tubuh sebagai tinja cair. Contoh klasik sekretorik adalah kolera. Kolera memproduksi enterotoksin yang mengaktivasi adenil siklase dan menyebabkan peningkatan siklik AMP yang berakibat sekresi aktif $\mathrm{Cl}-$, sedangkan Escherichia coli, Yersinia enterocolitica dan Klebsiella pneumoniae memproduksi enterotoksin yang meningkatkan siklik GMP.

\section{Diare osmotik}

Disebabkan meningkatnya osmolaritas intra luminal, misalnya absorbsi larutan dalam lumen kolon yang buruk. ${ }^{1}$ Sebagai contoh adalah diare yang yang disebabkan Rotavirus. Infeksi Rotavirus umumnya mengenai jejunum, tetapi dapat difus menyebar mengenai seluruh usus halus sehingga menimbulkan diare yang hebat. Virus ini menimbulkan diare dengan cara menginvasi epitel vili sehingga terjadi kerusakan sel yang matur. Sel matur ini akan diganti dengan sel imatur yang berasal dari proliferasi sel-sel kripta. Sel imatur ini mempunyai kapasitas absorbsi yang kurang dibandingkan dengan sel matur dan aktifitas disakaridase yang terdapat di sel imatur ini masih kurang sehingga terjadi gangguan pencernaan karbohidrat. Adanya karbohidrat (laktase) yang tidak dapat diabsorpsi, setelah mencapai usus besar akan difermentasi bakteri menjadi asam organik sehingga menyebabkan suasana hyperosmolar yang kemudian dapat mengakibatkan sekresi air ke dalam lumen usus.

Kedua hal patomekanisme ini dapat terjadi invasi dan destruksi pada sel epitel, penetrasi ke lamina propria serta kerusakan mikrovili usus yang dapat menimbulkan keadaan maldigesti dan malabsorpsi. Bila tidak mendapatkan penanganan yang adekuat pada akhirnya dapat mengalami invasi sistemik. ${ }^{7}$ Dalam revisi ke-4 WHO tahun 2005 mengenai tatalaksana diare cair akut pada anak menyebutkan tujuan pengobatan diare akut pada anak adalah: ${ }^{8}$

1. Pencegahan dehidrasi: bila tidak dijumpai tanda-tanda dehidrasi.

2. Pengobatan dehidrasi: bila dijumpai tandatanda dehidrasi (Tabel 1)

3. Mencegah timbulnya kurang kalori protein: dengan cara memberikan makanan selama diare berlangsung dan setelah diare berhenti. 
4. Mengurangi lama dan beratnya diare dan mengurangi kekambuhan diare pada masamasa mendatang dengan memberikan zink dengan dosis 10 sampai $20 \mathrm{mg}$ selama 10 sampai 14 hari.

Tabel 1. Penentuan Derajat Dehidrasi pada Diare ${ }^{8}$

\begin{tabular}{|c|c|c|c|}
\hline Tanda & $\begin{array}{c}\text { Tanpa } \\
\text { dehidrasi }\end{array}$ & $\begin{array}{c}\text { Dehidrasi } \\
\text { ringan- } \\
\text { sedang } \\
\end{array}$ & $\begin{array}{c}\text { Dehidrasi } \\
\text { Berat }\end{array}$ \\
\hline $\begin{array}{l}\text { Keadaan } \\
\text { umum }\end{array}$ & Baik, Sadar & Gelisah & $\begin{array}{l}\text { Letargi/tidak } \\
\text { Sadar }\end{array}$ \\
\hline Mata & Normal & Cekung & Sangat cekung \\
\hline Rasa haus & $\begin{array}{l}\text { Minum biasa, } \\
\text { tidak haus }\end{array}$ & Sangat haus & $\begin{array}{l}\text { Tidak Bisa } \\
\text { minum }\end{array}$ \\
\hline $\begin{array}{l}\text { Turgor } \\
\text { kulit }\end{array}$ & $\begin{array}{l}\text { Kembali } \\
\text { cepat }\end{array}$ & $\begin{array}{l}\text { Kembali } \\
\text { lambat }\end{array}$ & $\begin{array}{l}\text { Kembali } \\
\text { sangat lambat } \\
\text { ( } \geq 2 \text { detik) }\end{array}$ \\
\hline
\end{tabular}

Keterangan. Kesimpulan derajat dehidrasi ditentukan bila dijumpai $\geq 2$ gejala / tanda pada kolom yang sama.

Menurut WHO pemberian oralit dapat untuk mengganti cairan yang hilang melalui diare. Pemberian oralit berguna untuk mencegah terjadinya dehidrasi dan mengobati dehidrasi (terapi) pada diare akut. Bila pemberian oralit gagal, dilakukan pemberian cairan secara intravena dan penderita harus dirawat di rumah sakit. Pemberian cairan dilakukan berdasarkan derajat dehidrasi yang terjadi. ${ }^{2,8}$

\section{Selenium}

Selenium ditemukan pertama kali pada tahun 1817 oleh Jons Jakob Berzelius, seorang ahli kimia yang berasal dari Swedia. Pada penelitian tahun 1957 melaporkan bahwa selenium dapat mencegah nekrosis hepar pada tikus yang mengalami defisiensi vitamin E. Pada manusia, fungsi selenium baru ditemukan pada tahun 1973. Dr. John Rottuck dari Universitas Wisconsin menemukan bahwa selenium dapat bergabung dalam molekul suatu enzim yang disebut glutathione peroksidase (GPx). Sejak itu, terutama tahun 1980-an informasi mengenai selenium meningkat dengan cepat. ${ }^{9}$

Selenium merupakan trace element yang baik bagi kesehatan dan diperlukan tubuh dengan jumlah yang sangat kecil ${ }^{10}$ yang fungsinya untuk sistem kekebalan tubuh dan defisiensi selenium mempengaruhi terjadinya perkembangan beberapa penyakit infeksi virus. ${ }^{6}$ Selain itu selenium juga merupakan anti oksidan dan anti inflamasi. Beberapa efek positif dari intake selenium pada kesehatan manusia adalah: ${ }^{9}$
1. Stimulasi sistem imun, khususnya fungsi neutrofil, makrofag, sel NK, limfosit $\mathrm{T}$ dan pembentukan anti bodi

2. Modulasi produksi sitokin (meningkatkan IL2, menurunkan TNF, IL-8

3. Efek preventif terhadap inflamasi (menurunkan aktivitas NF- $\mathrm{BB}$ dan produksi sitokin pro-inflamasi

4. Proteksi sel dari efek buruk stress oksidatif dan radikal bebas

5. Efek preventif terhadap spontaneous tumors (efek sitotoksik langsung, stimulasi apoptosis sel-sel tumor

6. Proteksi kulit terhadap efek negatif dari radiasi UV (melanoma malignan)

7. Reduksi virulensi virus

8. Reduksi risiko aterosklerosis dan penyakit kardiovaskular

9. Modifikasi motilitas dan fungsi sperma pada laki-laki subfertil

10. Prevensi depresi dan kondisi psikis negatif lainnya

Sumber selenium terbaik pada makanan adalah sayuran, gandum, beras merah, dan beberapa daging dan makanan laut. Kandungan selenium bervariasi tergantung dengan kadar selenium dari tanah.10 Selenium terdapat dalam makanan dan tubuh manusia dalam dua bentuk yaitu organik dan bentuk inorganik. ${ }^{9,11}$ Dalam tubuh manusia, selenium terutama terdapat di otot, hati, darah, ginjal, jantung dan paru. Absorbsi selenium dalam lumen usus diduga berperan dalam pengaturan homeostasis selenium. Dalam bentuk organik, selenium diserap hampir 100\% sedangkan absorbsi selenium anorganik dipengaruhi oleh berbagai faktor lumen usus, namun diperkirakan masih diatas 50\%.12

Homeostasis dari selenium diatur dalam mekanisme ekskresi. Apabila masukan selenium meningkat dari tingkat kurang ke cukup, dan sebagian besar di absorbsi dalam lumen usus, maka ekskresi selenium lewat urin ditingkatkan sebagai mekanisme utama homeostasis. ${ }^{12}$ Sedangkan bila masukan lebih tinggi lagi, maka ekskresi lewat paru meningkat pula sebagai mekanisme sekunder homeostasis. ${ }^{12,13}$

Mikronutrien ini menjadi bagian yang penting dari enzim yang tergantung selenium, yang disebut selenoprotein. Terdapat 25 selenoprotein yang telah teridentifikasi, beberapa diantaranya enzim glutathione peroksidase (5 jenis), 
iodothyronine deiodinase ( 3 jenis). Selenoprotein Glutathione peroxidase (GPx1 sampai GPx4) memiliki karakteristik antara lain sebagai enzim antioksidan, eliminasi $\mathrm{H} 2 \mathrm{O} 2$ dan hidro peroksida organik, regulasi produksi prostanoid, regulasi reaksi inflamasi dan perlindungan membran biologis dan DNA.9,11,13

Selenium merupakan elemen yang diperlukan untuk fungsi selular normal, tetapi dapat memiliki efek toksik pada dosis tinggi. Dengan dosis asupan batas atas toleransi $400 \mu \mathrm{g}$ per hari. Menurut penelitian di Atlanta tahun 2010 gejala toksik selenium antara lain: diare (78\%), fatique $(75 \%)$, rambut rontok (72\%), perubahan warna kerapuhan kuku (61\%), mual (58\%). ${ }^{15}$ Menurut penelitian di New York pada tahun 1991 menjelaskan indikator awal keracunan selenium adalah bau nafas seperti bawang putih, kelainan dermatologi, gangguan gastrointestinal (dyspepsia, diare, anoreksia). ${ }^{14}$

\section{Peranan Selenium sebagai Sistem Imun dan Antioksidan}

Selenium merupakan komponen penting dari selenosistein yang terlibat dalam sebagian besar aspek dalam fungsi dan biokimia sel. Dengan demikian, ada banyak potensi selenium dalam mempengaruhi sistem imun tubuh baik sistem imun spesifik dan non spesifik. ${ }^{16}$ Beberapa peran selenium yang telah diketahui antara lain meningkatkan sistem imun untuk melawan virus, sebagai antioksidan, aktivitas sebagai anti kanker, pengaturan hormon tiroid dan lain-lain. ${ }^{17}$ Selenium diperlukan untuk berfungsinya neutrofil, makrofag, sel $\mathrm{NK}$, limfosit $\mathrm{T}$ dan beberapa mekanisme kekebalan tubuh lainnya. ${ }^{9}$

Sebagai bagian dari enzim yang mengandung selenium yang disebut selenoprotein. Salah satu kelompok dari selenoprotein adalah Glutatione Peroksidase (GPx) yaitu enzim yang berfungsi mengkatabolisme (H2O2) dan merupakan enzim antioksidan. Terdiri dari 5 jenis enzim yang mengandung selenium yaitu cellular glutathioneperoksidase (GPx1/cGPx), gastrointestinal glutathione peroksidase (GPx2/GPx GI), ekstraseluler glutathione peroxidase (GPx3/ eGPx), phospholipid hydroperoxide (GPx4), Glutathione peroxidase-6 (GPx6). ${ }^{18}$ Pada umumnya defisiensi selenium dapat menekan efektifitas sistem imun. ${ }^{19}$
Suplementasi selenium sangat dibutuhkan untuk mencapai sistem imun yang optimal, meskipun mekanismenya belum sepenuhnya dipahami. ${ }^{16}$ Tingginya asupan selenium mungkin terkait dengan berkurangnya risiko penyakit kanker, dan dapat mengurangi kondisi patologis lainnya termasuk stress oksidatif dan peradangan. $^{9}$ Beberapa penelitian yang memperlihatkan peranan selenium dalam mengoptimalkan sistem imun dan sebagai antioksidan antara lain penelitian pada tahun 1994 di New York memperlihatkan bahwa suplementasi selenium memiliki efek imunostimulan, termasuk terlihat peningkatan proliferasi sel T teraktivasi. Kelompok yang diberi suplemen selenium $200 \quad \mu \mathrm{g}$ per hari memperlihatkan peningkatan respons stimulasi antigen dan peningkatan kemampuan limfosit $\mathrm{T}$ sitotoksik sebesar 118\%. Aktivitas sel NK juga terlihat meningkat sebesar 82\%.1,20 Beberapa temuan menunjukkan bahwa defisiensi selenium dapat menjadi faktor risiko pada penyakit jantung. ${ }^{9}$ Peranan selenium pada sistem imun mulai diteliti pada kasus endemik cardiomyopathy di China, dimana kandungan selenium pada tanahnya rendah. ${ }^{21,22}$

Meningkatnya ekspresi kemokin disebabkan peningkatan stress oksidatif akibat defisiensi selenium. Adanya defisiensi selenium, yang merupakan komponen enzim Glutathione Peroksidase (GPx) akan mengganggu sistem pertahanan terhadap stress oksidatif. Hal ini akan berakibat meningkatnya stress oksidatif di kelompok tersebut. Dengan meningkatnya stress oksidatif ini akan meningkatkan aktifitas faktor nuklear $\kappa B \quad(N F-\kappa B)$ dan selanjutnya meningkatkan produksi kemokin, termasuk RANTES dan MCP-1. Ekspresi yang berlebihan dari kemokin ini akan menyebabkan migrasi selsel inflamasi yang lebih banyak ke jaringan terinfeksi yang memperparah proses peradangan. ${ }^{22}$

\section{Efektifitas Selenium pada Diare Cair Akut}

Diare cair akut adalah diare yang disebabkan infeksi virus, parasit, bakteri. Beberapa mikroorganisme yang menyebabkan diare cair akut, yaitu: Rotavirus, Escherichia Coli enterotoksigenik, Shigella, Campylobacter jejuni, dan Cryptosporidium, Vibrio cholera, Salmonella dan E. coli enteropatogenik. ${ }^{14}$ Beberapa 
pemeriksaan yang diperlukan untuk menegakkan diare cair akut, diantaranya dengan pemeriksaan makroskopis ditemukan tinja cair, tanpa mukus dan darah. Pada pemeriksaan mikroskopis tidak dijumpai adanya leukosit dalam feses. ${ }^{23}$

Penelitian tentang peranan selenium terhadap diare sangat sedikit. Sejauh ini selenium sebagai mikronutrien yang penting, yang diperlukan fungsinya untuk sistem kekebalan tubuh spesifik dan non spesifik, defisiensi selenium mempengaruhi terjadinya virulensi, atau perkembangan beberapa penyakit infeksi virus. ${ }^{6}$ Di samping itu penelitian-penelitian sebelumnya mengenai hubungan antara selenium dengan penyakit akibat virus, terlihat selenium yang cukup dapat memberikan kontribusi positif dalam proses penyembuhan. ${ }^{9}$

Gastrointestinal glutathione peroxidase (GPx2/GPx GI) paling banyak ditemukan di mukosa epitel traktus gastrointestinal. Aktifitas GPx GI dan GPx1 dapat ditemukan dalam traktus gastrointestinal bagian tengah dan bawah, terutama pada kripta dan vili usus. GPx GI pada vili berfungsi untuk melindungi epitel vili, sedangkan vilinya sendiri dilindungi eGPx. ${ }^{24}$

Pada diare yang disebabkan virus pada manusia secara selektif menginfeksi lapisan epitel dan menghancurkan sel-sel ujung vili pada usus halus. Hal ini menyebabkan absorbsi usus halus terganggu sehingga terjadi defisiensi selenium. Penurunan selenium mengakibatkan turunnya enzim GPx yang bersifat anti oksidan sehingga menyebabkan meningkatnya stres oksidatif. Stres oksidatif yang meningkat ini akan mengaktivasi NF- $\kappa B$ yang selanjutnya meningkatkan produksi kemokin seperti RANTES, MCP-1, IL-8, akibatnya migrasi sel-sel radang ke lokasi infeksi semakin meningkat dimana hal ini dapat memperparah proses peradangan. ${ }^{20}$ Selain itu defisiensi mengakibatkan penurunan aktifitas GPx pada neutrofil sehingga mengurangi kemampuannya untuk membunuh kuman patogen yang tertelan. ${ }^{25}$ Defisiensi selenium dapat menurunkan differensiasi dan proliferasi sel $\mathrm{T}$ dan menurunkan toksisitas limfosit T.26,27 Pada diare akut cair yang disebabkan rotavirus, limfosit $\mathrm{T}$ dan neutofil diperlukan untuk menghancurkan enterosit sehingga dapat mencegah perkembangan rotavirus lebih lanjut.

\section{Simpulan}

Diare cair akut merupakan salah satu manifestasi gangguan fungsi saluran cerna dan merupakan proses yang berhubungan suatu stress oksidatif. Selenium yang mengandung enzim mengurangi stress oksidatif sehingga berperan dalam proses penyembuhan diare akut.

\section{Daftar Pustaka}

1. Santosa B. Tatalaksana diare cair akut dalam naskah lengkap Kongres Nasional III Badan Koordinasi Gastroenterologi Anak Indonesia. In: Penanganan optimal masalah saluran cerna dan hati pada anak. Surabaya: BGKAI, 2007, pp. 35-45.

2. Subagyo B, Santoso N. Diare Akut. In: Juffrie M, Soenarto S, Oswari H, et al. (eds) Buku ajar Gastroenterologi- hepatologi. Jakarta: IDAI, 2010, pp. 87-120.

3. Kementerian Kesehatan Republik Indonesia. Situasi Diare di Indonesia. Jakarta, 2011.

4. Brown. Diarrhea and malnutrition. J Nutr. 2003; 133: 328-332.

5. Aggarwal R, Sentz J, Miller MA. Role of zinc administration in prevention of childhood diarrhea and respiratory illnesses: A meta-analysis. Pediatrics. 2007; 119: 1120-1130.

6. Ölmez A, Yalçin S, Yurdakök K, Coşkun T. Serum selenium levels in acute gastroenteritis of possible viral origin. J Trop Pediatr. 2004; 50: 78-81.

7. Ramig R. Pathogenesis of Intestinal and Systemic Rotavirus Infection. J Virol. 2004; 78: 10213-10220.

8. Womack NC. Treatment of diarrhea. Geneva: World Health Organization, 2005. Epub ahead of print 2005. DOI: 10.1097/00007611-192408000-00004.

9. Ferencik M, Ebringer L. The modulatory role of selenium and zinc on the immune system. Klin Immunol a Alergol. 2002; 12: 9-18.

10. Journal A, Biotechnology OF. The role of micronutrients in child health: A review of the literature The role of micronutrients in child health : A review of the literature. African J Biotechnol. 2016; 7: 3804-3810.

11. Tinggi U. Selenium: Its role as an antioxidant in human health. Environ Health Prev Med. 2008; 13: 102-108.

12. Satoto. Selenium dan kurang yodium. J GAKY Indones (Indonesian J IDD). 2002; 1: 33-42.

13. Fan AM, Kizer KW. Selenium. Nutritional, toxicologic, and clinical aspects. West J Med. 1990; 153: 160-167.

14. Litov RE, Combs GF. Selenium in pediatric nutrition. Pediatrics. 1991; 87: 339-351.

15. MacFarquhar JK, Broussard DL, Melstrom $P$, Hutchinson R, Wolkin A, Martin C, et al. Acute selenium toxicity associated with a dietary supplement. Arch Intern Med. 2010; 170: 256-261.

16. Ibs K-H, Function ZI, Rink L. Selenium in the immune system. Sci York. 2003; 133: 1452S-6S.

17. Zoidis E, Seremelis I, Kontopoulos N, Danezis GP. Selenium-dependent antioxidant enzymes: Actions and properties of selenoproteins. Antioxidants. 2018; 7: 1-26.

18. Jurkovič S, Osredcar J, Marc J. Molecular impact of glutathione peroxidases in antioxidant processes. Biochem Medica. 2008; 18: 162-174. 
19. Thomson CD. Assessment of requirements for selenium and adequacy of selenium status: A review. Eur J Clin Nutr. 2004; 58: 391-402.

20. Kiremidjian-Schumacher L, Roy M, Wishe HI, Cohen MW, Stotzky G. Supplementation with selenium and human immune cell functions - II. Effect on cytotoxic lymphocytes and natural killer cells. Biol Trace Elem Res. 1994; 41: 115-127.

21. Beck M a, Levander 0 a, Handy J. Oxidative Stress Mediated by Trace Elements Selenium Deficiency and Viral Infection 1. J Nutr. 2003; 133: 1463-1467.

22. Beck MA. Nutritionally induced oxidative stress: Effect on viral disease. Am J Clin Nutr. 2000; 71: 1676-1679.

23. Bass DM. Rotavirus, Caliciviruses, and Astroviruses. In: Kliegman RM, Geme JWS, Blum NJ, et al. (eds) Nelson Textbook of Pediatrics. Philadelphia: Elsevier, 2020, p. 7022.

24. Wingler $\mathrm{K}, \mathrm{Mu}$ C. Gastrointestinal Glutathione Peroxidase Prevents Transport of Lipid Hydroperoxides in CaCo-2 Cells ". 2000; 420-430.

25. Boyne R, Arthur JR. The response of seleniumdeficient mice to Candida albicans infection. J Nutr. 1986; 116: 816-822.

26. Kiremidjian-Schumacher L, Roy M, Wishe HI, Cohen MW, Stotzky G. Regulation of cellular immune responses by selenium. Biol Trace Elem Res. 1992; 33: 23-35.

27. Kiremidjian-Schumacher L, Roy M, Wishe $H$, Cohen M, Stotzky G. Selenium, and Immune Cell Functions. Proc Soc Exp Biol Med. 1990; 193: 136-42. 